
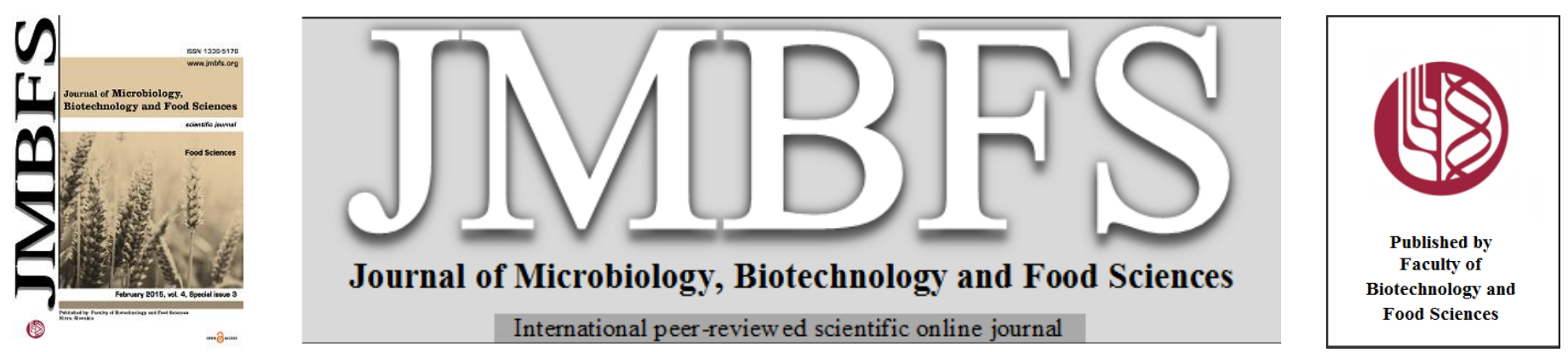

\title{
CHANGES IN THE ANTIOXIDANT CAPACITY OF POTATOES DEPENDING ON THE CULTIVAR, CONTENTS OF POLYPHENOLS, CHLOROGENIC ACID AND ASCORBIC ACID
}

\author{
Janette Musilova ${ }^{* 1}$, Judita Bystricka ${ }^{1}$, Beata Volnova ${ }^{1}$, Alzbeta Hegedüsova ${ }^{2}$, Matej Vesely ${ }^{3}$, Jan Heldak ${ }^{4}$
}

Address(es): doc. Ing. Janette Musilova, PhD.

${ }^{1}$ Slovak University of Agriculture in Nitra, Faculty of Biotechnology and Food Sciences, Department of Chemistry, Tr. A. Hlinku 2, 94976 Nitra, Slovak Republic, phone number: +421376414606

${ }^{2}$ Slovak University of Agriculture in Nitra, Faculty of Agrobiology and Food Resources, Department of Vegetable production, Tr. A. Hlinku 2, 94976 Nitra, Slovak Republic.

${ }^{3}$ Czech University of Life Sciences Prague, Faculty of Agrobiology, Food and Natural Resources, Department of Chemistry, Kamýcká 129,16521 Prague 6 - Suchdol, Czech Republic.

${ }^{4}$ Potato research and breeding institute, Popradská 518, 05952 Vel'ká Lomnica, Slovak Republic.

*Corresponding author: janette.musilova@uniag.sk

doi: 10.15414/jmbfs.2015.4.special3.125-129

\section{ARTICLE INFO}

Received 1.12.2014

Revised 6. 12. 2014

Accepted 7. 12. 2014

Published 2. 2. 2015

Regular article open $\partial_{\text {ACCESS }}$

\begin{abstract}
Effect of cultivar is known as the most important factor determining the qualit ative and quantitative characteristics of potatoes. In the st udy the influence of this factor on the content of chlorogenic acid (CGA), ascorbic acid (AA), total polyphenols (TPC) and antioxidant capacity (TAC) in six potato cultivars (Viola, Malvina, Evelin, Arlet, Megan, Timea) was investigated. Potatoes were grown in vitro on peat substrate in a greenhouse and were harvested in the st age of phy siological ripeness. The content of CGA, AA and the T AC were determined in fresh matter of potato tubers. CGA content was determined using standard HPLC gradient method. The lowest CGA amount was determined in cv. Viola $(18.49 \mathrm{mg} / \mathrm{kg} \mathrm{FM})$ and the highest one in cv. Megan $(46.73 \mathrm{mg} / \mathrm{kg} \mathrm{FM})$. The determined AA content was in interval $5.40 \mathrm{mg} / 100 \mathrm{~g} \mathrm{FM}$ (cv. Evelin) $-20.10 \mathrm{mg} / 100 \mathrm{gFM}$ (cv. Viola). Total antioxidant capacity expressed as $\mathrm{mg}$ eqv. Trolox/kg FM was the lowest in cv. Megan (41.06 mg TE/kg FM) and the highest in cv. Arlet (56.16 mg TE/kg FM). For TP content determination lyophilised potato samples were used. The determined values ranged from 256.44 until $425.37 \mathrm{mg} . \mathrm{kg}^{-1} \mathrm{DM}$ in followed order: Evelin < Arlet < Megan < Timea < Viola < Malvina. The obtained results were evaluated using one-factorial analy sis ANOVA (LSD-test), statistical software Stat graphic. Mutual correlations between the contents of CGA, AA, TP and T AC were evaluated using regression and correlation analysis (Microsoft Excel). Statistically significant dependence $(P$-value $<0.05)$ bet ween observed factors was confirmed.
\end{abstract}

Keywords: Potatoes, cultivar, chlorogenic acid, ascorbic acid, antioxidant capacity, polyphenols

\section{INTRODUCTION}

According to FAO dat a potato is as a global food crop ranking fourth among wheat, rice and maize. Their production in the world is of 368 million tons from 19.3 million hectares (Ahmadi et al., 2014).

Potato quality is affected by various factors of which the influence of culti var is the most important. Cultivar affects chemical and nutritional composition of potato tubers as well as morphological properties of the potato plant, the harvest time, resistance to pests, suitability for food processing and quantity of harvest (Galdón et al., 2012; Lachman et al.,2012; Ezekiel et al.,2013; Marchettini et al., 2013).

Besides a very appropriate nutritional composition potatoes are considered a good source of antioxidants in the human diet. The main antioxidants found in potatoes are polyphenols $(123-441 \mathrm{mg} / 100 \mathrm{~g})$, ascorbic acid $(8-54 \mathrm{mg} / 100 \mathrm{~g})$, carotenoids (up to $0.4 \mathrm{mg} / 100 \mathrm{~g}$ ) and tocopherols (to $0.3 \mathrm{mg} / 100 \mathrm{~g}$ ). Amino acid L-tyrosine represents a high proportion of antioxidants present in potato tubers. In lower concentrations also selenium and $\alpha$-lipoic acid are present. In potato cultivars with red and purple peel also anthocyanins were found which belong also to antioxidants (Vreugdenhil et al., 2007; Buono et al.,2009). Among the fruits and vegetables potatoes are considered the third largest source of antioxidants and phenolic compounds in the American diet following apples and oranges (Navaree $\boldsymbol{e t}$ al., 2011). There is growing evidence that under certain physiological conditions polyphenols may act as antioxidants and can protect plants against oxidative stress (André $\boldsymbol{e t ~ a l . , 2 0 0 9 )}$ ). Polyphenols are secondary met abolites of plants, which are divided in phenolic acids, flavonoids, stilbenes and lignans. This group consists from more than 8,000 identified substances (Perla et al., 2012; Ezekiel et al., 2013). Phenolic compounds are considered health promoting phytochemicals having besides antioxidant activity positive antiviral, anticarcinogenic, antiglycemic, anti-inflammatory and vasodilatory properties (Burgos et al., 2013).
Coffee, tea, fruit and green belong to food sources containing the highest concentration of polyphenols. On the other hand potatoes are considered one of the most important sources of dietary polyphenols in humans due to their frequent consumption (Daußer et al., 2012). Polyphenol compounds in potatoes are present in soluble (free, soluble esters or soluble glycosides) or insoluble form (Albishi et al., 2013), although phenolic compounds in potatoes were in the past considered undesirable because of enzymatic browning (Ezekiel et al., 2013). Potato polyphenols consist predominantly phenolic acids and flavonoids (Dau Ber et al., 2012). Phenolic acids represent about one third of polyphenols in the diet. They are represented by substituted derivatives of hydroxybenzoic acid and hydroxycinnamic acid, more common phenolics present in plants. These derivatives differ in hydroxylation and metoxylation of their aromatic rings. Phenolic acids are present in plant tissues mostly in bound form. The most common derivatives of hydroxycinnamic acids are caffeic acid, $p$-coumaric acid and ferulic acid, which often occur in food in the form of simple esters of quinic acid or glucose. Chlorogenic acid is probably the best known bound hydroxycinnamic acid derivative, which represents ester of caffeic acid and quinic acid (Mattila, Hellstrom, 2007). Chlorogenic acid represents up to $80 \%$ of total polyphenols (Perla et al., 2012). Some authors refer to $90 \%$ share of this acid, while chlorogenic acid is present in potato tubers in the form of isomers as cryptochlorogenic acid, neochlorogenic acid and acid isochlorogenic (Lach man et al., 2006, 2013). Vitamin C (L-ascorbic acid) is another important secondary metabolite of plants, which acts as an antioxidant. It influences many physiological processes of cells, regulation of growth and aging (Hemavathi $\boldsymbol{e t}$ al., 2009). Ascorbic acid is the main biologically active form of vitamin C. It is oxidized reversibly to L-dehydroascorbic acid, which also exhibits biological activity. At the same time $o$-quinones to $o$-diphenols are oxidized (Hernández $e t$ al., 2006). Ascorbic acid has an important role in protection against oxidative stress, free radical scavengign and prevents cancer, cardiovascular and other neurodegenerative diseases (Burgos et al., 2009). People during evolution lost 
the ability to synthesize this vitamin and therefore have to receive vitamin $\mathrm{C}$ in the diet (Hemavathi et al., 2009). The vitamin C requirement is covered by food especially potatoes, which are a very good source of vitamin C (20-30\%) due to their frequent consumption, followed by vegetables (about $30-40 \%$ ) and fruit $(30-35 \%)$. Milk covers the daily requirement of less than $10 \%$, depending on the eating habits of the consumer (Velíšek, Hajšlová, 2009).

The aim of the study was to research the cultivar impact on the content of important chemoprotective components of potatoes - chlorogenic acid, ascorbic acid, total polyphenols and related changes in antioxidant activity. The second part of the work was focused on the mutual correlations between the monitored parameters.

\section{MATERIAL AND METHODS}

Plant material - potatoes (Solanum tuberosum L.)

Cultivars:

Viola: early cultivar, shape of tubers - oval, colour of skin/flesh yellow/yellow, cooking type - B-BA

Malvina: early cultivar, shape of tubers - long oval, colour of skin/flesh yellow/yellow, cooking type $-\mathrm{B}$;

Evelin: mid - early cultivar, shape of tubers - oval, colour of skin/flesh yellow/yellow, cooking type - B;

Arlet: mid - early cultivar, shape of tubers - long oval, colour of skin/flesh yellow/yellow, cooking type - B;

Megan: mid - early cultivar, shape of tubers - oval, colour of skin/flesh yellow/yellow, cooking type - BC;

Timea: mid - early cultivar, shape of tubers - short-oval, colour of skin/flesh - yellow/yellow, cooking type - B-BC.

The procedure for obtaining the first tuber generation of cultivars Potato Research and Breeding Institute (PRBI):

in vitro plants with well-developed root system and a height of approximately $40 \mathrm{~mm}$ were planted in a peat substrate (layer: about $150 \mathrm{~mm}$ ) in a greenhouse in a buckle $100 \times 100 \mathrm{~mm}$;

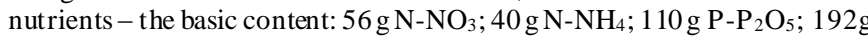

$\left.\mathrm{K}-\mathrm{K}_{2} \mathrm{O} ; 20 \mathrm{~g} \mathrm{Mg}-\mathrm{MgO}\right)+200$ g NPK $(15: 15: 15)$;

irrigation during the vegetation - as needed;

protection against Phytophthora infestans and transportes of viral diseases in 10-day intervals;

collection - in physiological ripeness of plants;

storage - at $15^{\circ} \mathrm{C}$ with gradual cooling to $8{ }^{\circ} \mathrm{C}$ and then transferring to the cooling box at $4{ }^{\circ} \mathrm{C}$.

Skinned tubers were used for the analysis.

Determination of total polyphenol content (TPC) spectrophotometrically (Spectrophotometer UV-VIS 1601, Shimadzu). Total polyphenol content was determined in ethanolic extracts using Folin-Ciocalteu agens. Analysis conditions: extraction of samples using T wisselman Extractor $80 \%$ EtOH ( Sigma
- Aldrich, Germany), duration of extraction $12 \mathrm{~h}$, preparation of samples for spectrophotometric determination according to Lachman et al. (2006), measurement of absorbance (against blank) at wavelength $\lambda=765 \mathrm{~nm}$. TPC was expressed as mg gallic acid eqv. to kg of dry matter.

Determination of chlorogenic acid (CGA) using standard HPLC gradient method (Waters Separation module 2696 with DAD detector Waters 2996). Chlorogenic acid was extracted with methanol (Chroma solv for HPLC, $\geq 99.9 \%$ (Sigma - Aldrich, Germany) and the aliquots where transferred into the vial. Chromatographic conditions: HPLC column RP-18 Purospher $(5 \mu \mathrm{m}), 250$ x 4 $\mathrm{mm}$ (Merck, Germany), column temperature $30^{\circ} \mathrm{C}$, flow rate $0.6 \mathrm{~mL} / \mathrm{min}$, DAD detector set to wavelength $\lambda=324 \mathrm{~nm}$, mobile phase acetic acid:methanol 10:90 (v/v), injection aliquot $20 \mu \mathrm{L}$, retention time $\mathrm{Rt}=4.6 \mathrm{~min}$.

De te rmination of ascorbic acid (AA) using standard HPLC gradient method (Waters Separation module 2696 with DAD detector Waters 2996). The aliquots of the extract (extraction of samples using meta-Phosphoric acid, homogenization, filtration) were taken for HPLC analysis using syringe filter (PTFE $0.45 \mu \mathrm{m}$, Teknokroma). Chromatographic conditions: HPLC column NovaPakC18 $(4 \mu \mathrm{m}), 150 \times 3.4 \mathrm{~mm}$ (Waters, USA), column temperature $25^{\circ} \mathrm{C}$, flow rate $1.0 \mathrm{~mL} / \mathrm{min}, \mathrm{DAD}$ detector set to wavelength $\lambda=251 \mathrm{~nm}$, mobile phase MetOH:water $-5: 95(\mathrm{v} / \mathrm{v})$, injection aliquot $5 \mu \mathrm{L}$, retention time $\mathrm{Rt}=1.4 \mathrm{~min}$. Determination of total antioxidant capacity (TAC) using photochemiluminiscence method (Photochem Analytik Jena AG, Germany). Principle of TAC determination consists in optical excitation of a photosensitizer and a photochemical generation of superoxide anion radicals. The obtained data were processed using soft ware PCL SOFT (Germany) and the results (Quantity, nmol) were calculated according to equation $C=\left(Q^{*} D * M * V_{e}\right) /\left(V_{p} * W s\right) ; \mathrm{Q}-$ quantity (nmol), D - dilution (1:400), $\mathrm{M}-\mathrm{M}_{\text {trolox }}(250.3 \mathrm{~g} / \mathrm{mol}), \mathrm{V}_{\mathrm{e}}-$ extract volume $(100 \mathrm{~mL}), \mathrm{V}_{\mathrm{p}}$ - pipeted volume $(5 \mu \mathrm{L}), \mathrm{Ws}$ - weight sample $(\mathrm{mg})$. T AC is expressed as mg eqv. Trolox $/ \mathrm{kg} \mathrm{FM}$

All analysis were done in eight repetitions.

Statistical analysis. Results were statistically evaluated by the Analysis of Variance (ANOVA - Multiple Range Tests, Method: 95,0 percent LSD) using statistical software ST ATGRAPHICS (Centurion XVI.I, USA) and the regression and correlation analysis (Microsoft Excel) was used.

\section{RESULTS AND DISCUSSION}

The effect of the cultivar to the content of chlorogenic acid (CGA), ascorbic acid (AA), total polyphenols content (TPC) and total antioxidant capacity (TAC)

The average content of chlorogenic acid (Table 1), determined in 6 potato cultivars was in interval $18.49 \mathrm{mg} / \mathrm{kg}$ FM (cv. Viola) - $46.73 \mathrm{mg} / \mathrm{kg} \mathrm{FM} \mathrm{(cv.}$ Megan).

Table 1 Content of CGA, AA, TP and TAC

\begin{tabular}{lcccc}
\hline cultivar & CGA $(\mathbf{m g} / \mathbf{k g}$ FM) & AA $(\mathbf{m g} / \mathbf{1 0 0} \mathbf{g}$ FM $)$ & TP $(\mathbf{m g} / \mathbf{k g ~ D M})$ & TAC $(\mathbf{m g} / \mathbf{k g ~ F M})$ \\
\hline Viola & $18.49^{\mathrm{a}} \pm 0.964$ & $20.10^{\mathrm{e}} \pm 0.851$ & $402.47^{\mathrm{d}} \pm 15.641$ & $51.46^{\mathrm{c}, \mathrm{d}} \pm 0.646$ \\
\hline Malvina & $26.44^{\mathrm{c}} \pm 1.773$ & $9.77^{\mathrm{b}} \pm 0.367$ & $425.37^{\mathrm{e}} \pm 10.960$ & $52.28^{\mathrm{d}} \pm 1.165$ \\
\hline Evelin & $23.33^{\mathrm{b}} \pm 1.161$ & $5.40^{\mathrm{a}} \pm 0.223$ & $256.44^{\mathrm{a}} \pm 39.157$ & $43.86^{\mathrm{b}} \pm 1.125$ \\
\hline Arlet & $42.39^{\mathrm{d}} \pm 2.259$ & $14.48^{\mathrm{c}} \pm 0.633$ & $299.10^{\mathrm{b}} \pm 19.618$ & $56.16^{\mathrm{e}} \pm 1.376$ \\
\hline Megan & $46.73^{\mathrm{e}} \pm 2.513$ & $16.42^{\mathrm{d}} \pm 0.886$ & $357.65^{\mathrm{c}} \pm 13.986$ & $41.06^{\mathrm{a}} \pm 1.424$ \\
\hline Timea & $19.26^{\mathrm{a}} \pm 1.080$ & $10.04^{\mathrm{b}} \pm 0.433$ & $362.42^{\mathrm{c}, \mathrm{d}} \pm 7.542$ & $50.18^{\mathrm{c}} \pm 2.591$ \\
\hline Notes: Multiple Range Tests for CGA, AA, TP and TAC by cultivar; Method: 95,0 percent LSD & &
\end{tabular}

The obtained results are similar to those presented other authors: Daußer $\boldsymbol{e t ~ a l}$. (2012) determined in inner pulp $34.8 \pm 1.8 \mathrm{mg} \mathrm{CGA} / \mathrm{kgFM}$, in outer pulp $93.0 \pm$ $13.7 \mathrm{mg} \mathrm{CGA} / \mathrm{kg}$ FM and in peel even $1170 \pm 93.2 \mathrm{mg} \mathrm{CGA} / \mathrm{kg} \mathrm{FM}$; Chiou et al. (2007) present in inner pulp of cv. Charlotte only $2.1 \mathrm{mg} \mathrm{CGA} / \mathrm{kg}$ M; Velíšek (2002) refer content of chlorogenic acid in fresh potatoes in interval $100-200$ $\mathrm{mg} / \mathrm{kg}$, in cooked potatoes only about $35 \%$ of this amount and in baked potatoes chlorogenic acid in not present at all. The high content of CGA $(3070 \mathrm{mg} / \mathrm{kg} \mathrm{FM})$ was determined by André $\boldsymbol{e t ~ a l . ~ ( 2 0 0 7 ) ~ i n ~ i n n e r ~ p u l p ~ o f ~ v i o l e t ~ c v . ~ V i t e l o t t e . ~}$ Brown (2005) informs about 3 - 4 times higher content of phenolic acids in color (red, violet) cultivars compared to potato cultivars with yellow peel and pulp.
Our result s confirm the significant influence of potato cultivar on the content of CGA in tubers. Statistically significant differences in content of CGA between investigated potato cultivars were confirmed (no significant difference only bet ween cvs. Viola - Timea was observed) (Table 1).

Content of CGA, determined in peeled potatoes was in interval 20 do $58 \%$ of TPC (calculated on fresh matter, Figure 1). Chlorogenic acid, which represents even $90 \%$ of total polyphenol content in potatoes, is concentrated predominantly in peel and its content is decreased to the middle of the tuber (Lachman $\boldsymbol{e t}$ al., 2013). 


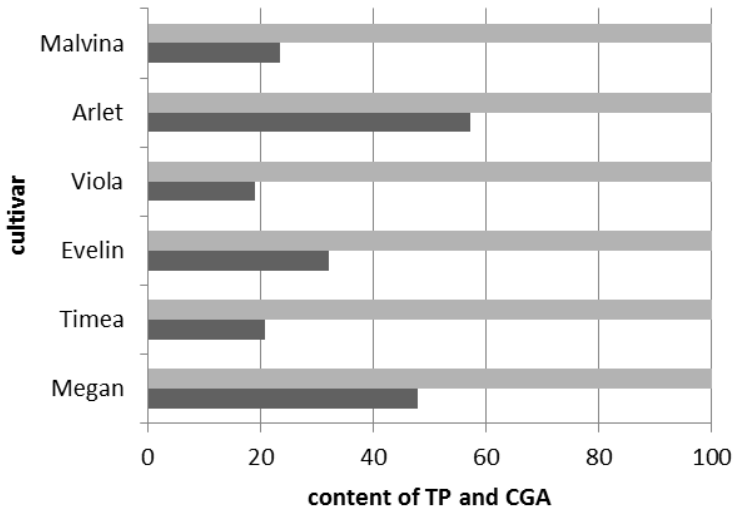

Figure 1 Portion of CGA of TP content in tubers of potato cultivars (\%)

The lowest content of ascorbicacid $(5.40 \mathrm{mg} / 100 \mathrm{~g} \mathrm{FM})$ was determined in cv. Evelin (Table 1) followe by Malvina, Timea, Arlet, Megan and Viola. (80.9, $86.0,168.2,204.0$ and $272.2 \%$ increase, respectively).

Our results correspond with those of Nordbotten and Løken (2000), who determined in Norwegian potato cultivars $8.4-20.1 \mathrm{mg}$ of C vitamin in $100 \mathrm{~g}$ FM as well as Han et al. (2004), who determined in Korean cultivars $16-46 \mathrm{mg}$ AA/100 g FM. Haase and Weber (2003) present in fresh potatoes the average content of C vitamin $94-98.9 \mathrm{mg} / 100 \mathrm{~g} \mathrm{DM}$.

Zrůst (2004) refer about relatively little impact of cultivar on the content of $\mathrm{C}$ vitamin in potatoes and about significant influence of a year (up 50\%) or different fertilization and/or nutrient support. Our results confirmed the significant impact of cultivar on the AA content in tubers. Statistically significant differences in content of $\mathrm{C}$ vitamin between investigated potato cultivars were confirmed (no significant difference only bet ween cvs. Malvina and Timea was observed) (Table 1). Similar results are presented also by other authors. He jtmánková (2011) determined content of $\mathrm{C}$ vitamin in potatoes in interval 109 - $315 \mathrm{mg} / \mathrm{kg} \mathrm{FM}$, while in yellow cultivars content of $\mathrm{C}$ vitamin was higher compared with color (red, violet) cultivars and in red cultivars were determined values higher in comparison with violet potatoes. Statistically significant differences in content of $\mathrm{C}$ vit amin bet ween 25 cultiv ars of Andean potatoes were confirmed by Burgos et al. (2012). Content of $\mathrm{C}$ vitamin in potatoes was in interval $22.2-121.4 \mathrm{mg} / 100 \mathrm{~g}$ FM. Higher content of $\mathrm{C}$ vitamin in comparison to our cultivars can be explained cultivar properties, because Andean cultivars are characteristic by higher content of $\mathrm{C}$ than other potato cultivars.

The lowest total polyphenol content, was determined in cv. Evelin (265.44 $\mathrm{mg} / \mathrm{kg} \mathrm{FM}$ ) followed by Arlet $(299.10 \mathrm{mg} / \mathrm{kg} \mathrm{FM})<\operatorname{Megan}(357.65 \mathrm{mg} / \mathrm{kg} \mathrm{FM})$

$<$ Timea ( $362.42 \mathrm{mg} / \mathrm{kg} \mathrm{FM})$. The highest TPC was determined in early cultivars Viola $(402.49 \mathrm{mg} / \mathrm{kg} \mathrm{FM})$ and Malvina $(425.37 \mathrm{mg} / \mathrm{kg} \mathrm{FM})$. Our values are lower in comparison to those presented by Lachman et al. (2006). These authors investigated differences in TPC in 6 cultivars ( 4 yellow, 2 violet). Violet cultivars contained 58,1\% higher amount of TPC compared with yellow cultivars which cont ained $2.46-3.44$ g. $\mathrm{kg}^{-1} \mathrm{DM}$. Differences between results can be affected by analysis of different preparated potato sample: TPC determination in whole potatoes (pulp + peel), resp. only pulp of potatoes (in our study).

Similarly as in previous cases, the statistical evaluation of the obtained results was done. Statistically significant differences in TPC were confirmed bet ween all investigated potato cultivars with exception of Viola - Malvina, Viola - Timea and Megan - Timea (Table 1).

Generally, cultivar is considered the most important factor influencing the content of total polyphenols. The results correspond with the results of Eze kiel $\boldsymbol{e t}$ al. (2013), who referred the content of total polyphenols in the pulp in the range of $30-900 \mathrm{mg} / \mathrm{g}$ DM and in peel $1000-4000 \mathrm{mg} / \mathrm{kg}$ DM. Similar results are presented also by Andre et al. (2009), who investigated the effect of the cultivar and environmental factors on polyphenol content of 13 Andean potato cultivars. Burgos et al. (2013) determined T PC in fresh potatoes $596-4196 \mathrm{mg} / \mathrm{kg}$ DM total polyphenols expressed as chlorogenic acid equivalents. Besides a cultivar, also year, condition of st orage and food processing of potateos have a smaller but significant impact affecting their polyphenol content (Lachman et al., 2008a Faller, Fialho, 2009; Galdón et al., 2012; Albishi et al., 2013; Ezekiel et al., 2013).

The content of chlorogenic acid, ascorbic acid and polyphenolic compounds (in the raw materials and foods) can significantly affect their total antioxidant capacity. Polyphenols belong to the main antioxidants of which phenolic acids (particularly chlorogenic acid) and flavonoids (especially anthocyanins present in red and violet cultivars) are the most commonly compounds found in potatoes. Vitamin C, carotenoids, $\alpha$-tocopherol, L-tyrosine, selenium, and $\alpha$-lipoic acid are another components with an antioxidant effect. At present, attention is given primarily to $\mathrm{C}$ vitamin $\mathrm{C}$, content of total polyphenols, phenolic acids and anthocyanins, as well as to fact ors affecting the value of total antioxidant activity (Lachman et al., 2008a; Rumbaoa et al., 2009; Al-Weshahy et al., 2013 ). Values of T AC expressed in $\mathrm{mg} \mathrm{TE} / \mathrm{kg}$ FM were in range $41.05 \mathrm{mg} / \mathrm{kg} \mathrm{FM} \mathrm{(cv}$ Megan) $-56.17 \mathrm{mg} / \mathrm{kg} \mathrm{FM} \mathrm{(cv.} \mathrm{Arlet).} \mathrm{Although} \mathrm{the} \mathrm{statistically} \mathrm{significant}$ differences in T AC between investigated cultivars (with exception of MalvinaViola and Timea - Viola) were confirmed (Table 1), the difference between the minimum and maximum TAC was only $36.8 \%$. In cultivars with violet pulp the significantly higherantioxidant activity was confirmed compared to cultivars with yellow pulp (Lachman et al., 2006; Brown et al., 2003; Hejtmánková, 2011).

Cross-correlation between the content of chlorogenic acid (CGA), ascorbic acid (AA), total polyphenols content of (TPC) and total antioxidant capacity (TAC)

Mutual correlations between the contents of CGA, AA, TP and T AC were evaluated using regression and correlation analysis.

Table 2 Cross-correlation between CGA and T AC

\begin{tabular}{lcccc}
\hline cultivar & Multiple R & R Square & Regression equation & P-value \\
\hline Viola & 0.911 & 0.830 & $\mathrm{y}=0.6106 \mathrm{x}+40.173$ & $1.650 \mathrm{E}-03$ \\
\hline Malvina & 0.961 & 0.924 & $\mathrm{y}=0.8483 \mathrm{x}+29.852$ & $1.398 \mathrm{E}-04$ \\
\hline Evelin & 0.946 & 0.895 & $\mathrm{y}=0.9171 \mathrm{x}+22.456$ & $3.735 \mathrm{E}-04$ \\
\hline Arlet & 0.934 & 0.873 & $\mathrm{y}=0.5955 \mathrm{x}+30.915$ & $6.802 \mathrm{E}-04$ \\
\hline Megan & 0.941 & 0.886 & $\mathrm{y}=0.5333 \mathrm{x}+16.135$ & $4.831 \mathrm{E}-04$ \\
\hline Timea & 0.940 & 0.883 & $\mathrm{y}=2.2545 \mathrm{x}+6.7591$ & $5.262 \mathrm{E}-04$ \\
\hline Notes: regression and & & &
\end{tabular}

Strong positive correlation (correlation coefficient $\mathrm{R}>0.9$ ) was confirmed between the content of chlorogenic acid and total antioxidant capacity in all cultivars, the regression coefficient is st atistically significant for all cultivars $(\mathrm{P}$ value $<0.05$ ) (Table 2). The results correspond with those presented by Hejtmánková (2011), who refer about a strong correlation between CGA and $\mathrm{T} A C$ in potatoes. Phenolic acids and their derivatives show the effects of primary antioxidants. Phenolic acids, such as chlorogenic acid, caffeic acid, protocatechuic acid, and $p$-coumaric acid contribute to the antioxidant activity of potatoes. These compounds were most frequently identified in potatoes with pink and red pulp (Velíšek 2002, Vreugdenhil et al., 2007).

Table 3 Cross-correlation between AA and T AC

\begin{tabular}{lcccc}
\hline cultivar & Multiple R & R Square & Regression equation & P-value \\
\hline Viola & 0.960 & 0.921 & $\mathrm{y}=0.728 \mathrm{x}+36.829$ & $1.588 \mathrm{E}-04$ \\
\hline Malvina & 0.947 & 0.897 & $\mathrm{y}=3.0063 \mathrm{x}+22.922$ & $3.592 \mathrm{E}-04$ \\
\hline Evelin & 0.893 & 0.798 & $\mathrm{y}=4.5145 \mathrm{x}+19.476$ & $2.797 \mathrm{E}-03$ \\
\hline Arlet & 0.940 & 0.883 & $\mathrm{y}=2.0431 \mathrm{x}+26.564$ & $5.228 \mathrm{E}-04$ \\
\hline
\end{tabular}




\begin{tabular}{lllll}
\hline Megan & 0.970 & 0.942 & $\mathrm{y}=1.5596 \mathrm{x}+15.454$ & $6.341 \mathrm{E}-05$ \\
\hline Timea & 0.949 & 0.900 & $\mathrm{y}=5.6788 \mathrm{x}-6.8515$ & $3.226 \mathrm{E}-04$ \\
\hline Notes: regression a correlation analysis (Microsoft Excel) & & &
\end{tabular}

In all cultivars a strong positive correlation between the content of ascorbic acid and total antioxidant capacity was confirmed (correlation coefficient $\mathrm{R}>0.89$ ). For a description of dependencies linear regression lines were used, which explain the variability of TAC at minimum $79.8 \%$ (cv. Evelin) (Table 3).
Ascorbic acid may exhibit under certain conditions antioxidant effects. It may act as a scavenger of oxygen, as a hydrogen donor for phenolic compounds and as a synergistic compound for some antioxidants. Ascorbic acid reacts with certain metals, reduces them and allows them to be more effective as prooxidants (Lachman et al., 2001).

Table 4 Cross-correlation between AA and T AC

\begin{tabular}{lcccc}
\hline cultivar & Multiple R & R Square & Regression equation & P-value \\
\hline Viola & 0.973 & 0.946 & $\mathrm{y}=0.0402 \mathrm{x}+35.294$ & $4.952 \mathrm{E}-05$ \\
\hline Malvina & 0.909 & 0.826 & $\mathrm{y}=0.0966 \mathrm{x}+11.207$ & $1.778 \mathrm{E}-03$ \\
\hline Evelin & 0.944 & 0.892 & $\mathrm{y}=0.0271 \mathrm{x}+36.896$ & $4.144 \mathrm{E}-04$ \\
\hline Arlet & 0.910 & 0.827 & $\mathrm{y}=0.0638 \mathrm{x}+37.072$ & $\mathrm{y}=0.1005 \mathrm{x}+5.0985$ \\
\hline Megan & 0.988 & 0.975 & $\mathrm{y}=0.3274 \mathrm{x}-68.463$ & $2.779 \mathrm{E}-06$ \\
\hline Timea & 0.953 & 0.908 & & \\
\hline
\end{tabular}

The results of regression and correlation analysis show that in all cultivars the statistical dependence between the determined total content of polyphenols and antioxidant activity was confirmed, which is the most significant in cultivar Megan (P-value = 4.779E-06) $($ Table 4). Lachman et al. $\mathbf{( 2 0 0 8 a , 2 0 0 8 b )}$ referred about a strong positive correlation between T AC and TPC in potatoes (yellow cultivars Karin, Impala, Dita, Saturna; purple cultivars Valfi, Violette). Also Lugasi et al. (1999), Reyes et al. (2005), Andre et al. (2009), Albishi et al. (2013), Al-Weshahy et al. (2013) confirmed a high positive correlation between T AC and T PC. On the other hand Rumbaoa et al. (2009) confirmed a negative correlation between the TPC and TAC in four Philippine potato cultivars, because not all phenolics present in potatoes have an antioxidant activity (Burgos et al., 2013).

\section{CONCLUSION}

A number of factors, such as year, agrochemical factors, mechanical tuber damage at harvest, storage conditions, and mostly cultivar, affect the content of chemoprotective components of potatoes. The cultivar impact was confirmed when evaluating the determined content of chlorogenic acid (Viola ${ }^{\mathrm{a}}$, Timea ${ }^{\mathrm{a}}$, Evelin $^{\mathrm{b}}$, Malvina $^{\mathrm{c}}$, Arlet $^{\mathrm{d}}$, Megan $\left.^{\mathrm{e}}\right)$, ascorbic acid (Evelin ${ }^{\mathrm{a}}$, Malvina ${ }^{\mathrm{b}}$, Timea ${ }^{\mathrm{b}}$,

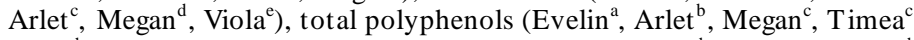
Viola $^{\mathrm{d}}$, Malvina $\left.^{\mathrm{e}}\right)$ and antioxidant capacity $\left(\right.$ Megan $^{\mathrm{a}}$, Evelin $^{\mathrm{b}}$, Timea ${ }^{\mathrm{c}}$, Viola ${ }^{\mathrm{c}, \mathrm{d}}$ Malvina $^{\mathrm{d}}$, Arlet $^{\mathrm{e}}$ ) in almost all cultivars.

Chlorogenic acid, ascorbic acid and polyphenol compounds are classified as substances with antioxidant activity. In this study a correlations between CGA and T AC, TPC and T AC and T AC resp. AA in all cultivars were (P-value <0.05) confirmed.

For each analy sis pulp of peeled potatoes was used. In further research an interest in the potential of potato peel could be given, which contains a much higher amount of polyphenols and exhibit higher antioxidant activity than potato pulp, although it is often discarded as a by-product of the food processing. Already there are some studies on effective ways of these substances extraction. These studies are associated with proposals of using of potato pulp as a functional food, and as a source of fiber and antioxidants. The red and violet cultivars can be even used as a source of natural pigments.

Acknowledgments: Article was developed with the financial support by grant VEGA 1/0456/12 and VEGA 1/0290/14.

\section{REFERENCES}

AHMADI, H., AGHAREZAEE, M., KAMGAR-HAGHIGH, A.A., SEPASKHAH, A.R. 2014. Effects of dynamic and static deficit and partial root zone drying irrigation strategies on yield, tuber sizes distribution, and water productivity of two field grown potato cultivars. Agricultural Water Management, 134, 126-136. http://dx.doi.org/10.1016/j.agwat.2013.11.015 AL-WESHAHY, A., EL-NOKETY, M., BAKHETE, M., RAO, V. 2013. Effect of storage on antioxidant activity of freeze-dried potato peels. Food Research International, 50(2), 507-512.http://dx.doi.org/10.1016/j.foodres.2010.12.014 ALBISHI, T., JOHN, J.A., AL-KHALIFA, A.S., SHAHIDI, F. 2013. Phenolic content and antioxidant activities of selected potato varieties and their processing by-products. Journal of Functional Food, 5(2), 590-600. http://dx.doi.org/10.1016/j.jff.2012.11.019

ANDRÉ, C.M., OUFIR, M., GUIGNARD, C., HOFFMANN, L., HAUSMAN, J.F., EVERS, D. 2007. Antioxidant profiling of native Andean potato tubers
(Solanum tuberosum L.) reveals cultivars with high levels of beta-carotene, alpha-tocopherol, chlorogenic acid, and petanin. Journal of Agricultural and Food Chemistry, 55(26), 10839-10849. http://dx.doi.org/10.1021/jf0726583 ANDRÉ, C.M., OUFIR, M., HOFFMANN, L., HAUSMAN, J.F., ROGEZ, H., LARONDELLE, Y., EVERS, D. 2009. Influence of enviroment and genotype on polyphenol compounds and in vitro antioxidant capacity of native Andean potatoes (Solanum tuberosum L). Journal of Food Composition and Analysis, 22(6), 517-524. http://dx.doi.org/10.1016/j.jfca.2008.11.010

BROWN, C.R. 2005. Antioxidants in Potato. American Journal of Potato Research, 82(2), 163-172. http://dx.doi.org/10.1007/bf02853654

BROWN, C.R., WROLST AD, R., DURST, R., YANG, P., CLEVIDENCE, B. 2003. Breeding studies in potatoes containing high concentrations of anthocyanins. American Journal of Potato Research, 80(4), 241-249. http://dx.doi.org/10.1007/bf02855360

BUONO, V., ARADISO, A., SERIO, F., GONNELlA, M., GARA, L., SANTAMARIA, P. 2009. Tuber quality and nutritional components of „early“ potato subjected to chemical haulm desiccation. Journal of Food Composition and Analysis, 22(6), 556-562. http://dx.doi.org/10.1016/i.jfca.2009.01.001 BURGOS, G., AUGUI, S., AMOROS, W., SALAS, E., BONIERBALE, M. 2009. Ascorbic acid concentration of native Andean potato varieties as affected by enviroment, cooking and storage. Journal of Food Composition and Analysis, 22(6), 533-538. http://dx.doi.org/10.1016/j.jfca.2008.05.013

BURGOS, G., AMOROS, W., SALAS, E., MUNOA, L., SOSA, P., DÍAZ, C., BONIERBALE, M. 2012. Carotenoid concentrations of native Andean potatoes as affected by cooking. Food Chemistry, 133(4), 1131-1137. http://dx.doi.org/10.1016/j.foodchem.2011.09.002

BURGOS, G., AMOROS, W., MUNOA, L., SOSA, P., CAYHUALLA, E., SACHEZ, C., DIAZ, C., BONIERBALE, M. 2013. Total phenolic, total anthocyanin and phenolic acid concentrations and antioxidant activity of purplefleshed potatoes as affected by boiling. Journal of Food Composition and Analysis, 30(1), 6-12. http://dx.doi.org/10.1016/j.jfca.2012.12.001 CHIOU, A., SALT A, F.N., KALOGEROPOULOS, N., MYLONA, A.,

NT ALLA, I., ANDRIKOPOULOS, N.K. 2007. Retention and distribution of polyphenols after pan-frying of French fries in oils enriched with olive leaf extract. Journal of Food Science, 136(8), 5574-5584. http://dx.doi.org/10.1111/j.1750-3841.2007.00493.x

DAUßER, H., GUIGNARD, C., HOFFMANN, L., EVERS, D. 2012.Polyphenol and glycoalkaloid contents in potato cultivars grown in Luxemburg. Food Chemistry, $135(4)$, http://dx.doi.org/10.1016/j.foodchem.2012.07.028

EZEKIEL, R., SINGH, N., SHARMA, S., KAUR, A. 2013. Beneficial phytochemicals in potato - a review. Food Research International, 50(2), 487 496. http://dx.doi.org/10.1016/j.foodres.2011.04.025

FALLER, A.L.K., FIALHO,E. 2009. The antioxidant capacity and polyphenol content of organic and conventional retail vegetables after domestic cooking. Food Research International, 42(1), 210-215. http://dx.doi.org/10.1016/j.foodres.2008.10.009

GALDÓN, B.R., RODRÍGUEZ, L.H., MESA, D.R., LEÓN, H.L., PÉREZ, N.L., RODRÍGUEZ, E.M., ROMERO, C.D. 2012. Differentiation of potato cultivars experimentally cultivated based on their chemical composition and by applying linear discriminant analysis. Food Chemistry, 133(4), 1241-1248. http://dx.doi.org/10.1016/j.foodchem.2011.10.016

HAN, J.S., KOZUKE, N., YOUNG, K.S., LEE, K.R., FRIEDMAN, N. 2004. Distribution of ascorbic acid in potato tubers and in home-processed and commercial potato foods. Journal of Agricultural and Food Chem istry, 52(21), 
6516-6521. http://dx.doi.org/10.1021/jf0493270

HAASE, N.U, WEBER, L. 2003. Ascorbic acid losses during processing of French fries and potato chips. Journal of Food Engineering, 56(2-3), 207-209. http://dx.doi.org/10.1016/s0260-8774(02)00252-2

HEJTMÁNKOVÁ, K. 2011. Vliv faktorů na obsah vybraných ukazovatelů jakosti hlíz brambor : dizertační práca. Praha : ČZ, 2011. 110 p.

HEMAVATHI, CH., UPADHYAYA, P., YOUNG, K., AKULA, N., KIM, H., HEUN, J., ASWATH, CH., CHUN, S., KIM, D., PARK, W. 2009. Overexpression of strawberry D-galacturonic acid reductase in potato leads to accumulation of vitamin $\mathrm{C}$ with enhanced abiotic stress tolerance. Plant Science, 177(6), 659-667. http://dx.doi.org/10.1016/j.plantsci.2009.08.004

HERNÁNDEZ, Y., LOBO, G., GONZÁLEZ, M. 2006. Determination of vitamin $\mathrm{C}$ in tropical fruits: A comparative evaluation of methods. Food Chemistry, 96(4), 654-664. http://dx.doi.org/10.1016/j.foodchem.2005.04.012

LACHMAN, J., HAMOUZ, K., ORSÁK, M., PIVEC, V. 2001. Polyfenoly, askorbová kyselina a karotenoidy - významné antioxidanty $\mathrm{v}$ hlízách brambor. Bramborářství, IX(2), 6-8. ISSN 1211-2429.

LACHMAN, J., HAMOUZ, K., ČEPL, J., PIVEC, V., ŠULC, M., DVOŘÁK, P 2006. Vliv vybraných faktorů na obsah polyfenolů a antioxidační aktivitu hlíz brambor. Chemické listy, 100(7), 522-527. http://chemickelisty.cz/docs/full/2006_07_522-527.pdf

LACHMAN, J., HAMOUZ, K., ORSÁK, M., PIVEC, V., DVOŘ́́K, P. 2008a

The influence of flesh colour and growing locality on polyphenolic content and antioxidant activity in potatoes. Scientia Horticulturae, 117(2), 109-114. http://dx.doi.org/10.1016/j.scienta.2008.03.030

LACHMAN, J., HAMOUZ, K., ŠULC, M., ORSÁK, M., DVOŘÁK, P. 2008 b Differences in phenolic content and antioxidant activity in yellow and purplefleshed potatoes grown in the Czech Republic. Plant Soil and Environment, 54(1), 1-6.

http://www.agriculturejournals.cz/publicFiles/00566.pdf

LACHMAN, J., HAMOUZ, K., ORSÁK, M., PIVEC, V., HEJTMÁNKOVÁ, K. PAZDERŮ, K., DVOŘ́K, P., ČEPL, J. 2012. Impact of selected factors Cultivar, storage, cooking and baking on the content of anthocy anins in colouredflesh potatoes. Food Chemistry, 133(4), s. 1107-1116. http://dx.doi.org/10.1016/j.foodchem.2011.07.077

LACHMAN, J., HAMOUZ, K., MUSILOVÁ, J., HEJTMÁNKOVÁ, K., KOTÍKOVÁ, Z., PAZDERŮ, K., DOMKÁŘOVÁ, J., PIVEC, V., CIMR, J. 2013. Effect of peeling and three cooking methods on the content of selected phytochemical in potato tubers with various colour of flesh. Food Chemistry, 138(2-3), 1189-1197. http://dx.doi.org/10.1016/j.foodchem.2012.11.114 LUGASI, A., AL MEIDA, D.P.F., DWORSCHAK, E. 1999. Chlorogenic acid content and antioxidant properties of potato tubers as related to nitrogen $\begin{array}{llll}\text { fertilisation. Acta } & \text { alimentaria, } & \text { 28(2), }\end{array}$ http://dx.doi.org/10.1556/aalim.28.1999.2.7

MARCHETTINI, N., FOCARDI, S., GUARNIERI, M., GUERRANTI, C., PERRA, G. 2013. Determination of acrylamide in local and commercial cultivar of potatoes from biological farm. Food Chemistry, 136(3-4), 1426-1428. http://dx.doi.org/10.1016/j.foodchem.2012.09.077

MAT TILA, P., HELLSTROM, J. 2007. Phenolic acids in potatoes, vegetables, and some of their products. Journal of Food Composition and Analysis, 20(3-4), 152-160. http://dx.doi.org/10.1016/j.jfca.2006.05.007

NAVARRE, D.A., PILLAI, S.S., SHAKYA, R., HOLDEN, J.M. 2011. HPLC profiling of phenolics in diverse potato genotypes. Food chem istry, 127(1), 3441. http://dx.doi.org/10.1016/j.foodchem.2010.12.080

NORDBOT TEN, A., LØKEN, E.B. 2000. Sampling of Potatoes to Determine Representative Values for Nutrient Content in a National Food Composition Table. Journal of Food Composition and Analysis, 13(4), 369-377. http://dx.doi.org/10.1006/jfca.2000.0906

PERLA, V., HOLM, G.D., JAYANTY, S.S. 2012. Effects of cooking methods on polyphenols, pigments and antioxidant activity in potato tubers. $L W T-$ Food Science and Technology, 45(2), 161-171. http://dx.doi.org/10.1016/j.lwt.2011.08.005

REYES, L.F., MILLER JR., J.C., CISNEROS-ZEVALLOS, L. 2005 Antioxidant Capacity, Anthocyanins and Total Phenolics in Purpleand RedFleshed Potato (Solanum tuberosum L.) Genotypes. American Journal of Potato Research, 82(4), 271-277.

http://dx.doi.org/10.1007/bf02871956

RUMBAOA, R.G.O., CORNAGO, D.F., GERONIMO, I.M. 2009. Phenolic content and antioxidant capacity of Philippine potato (Solanum tuberosum) tubers. Journal of Food Composition and Analysis, 22(6), 546-550. http://dx.doi.org/10.1016/j.jfca.2008.11.004

VELÍŠEK, J. 2002. Chemie potravin III. Vyd. OSSIS - Tábor. 368 s. ISBN 80 86659-02-X.

VELÍŠEK, J., HAJŠLOVÁ, J. 2009. Chemie potravin I. T ábor : OSSIS, 2009, 602 s., ISBN 978-80-86659-15-2.

VREUGDENHIL, D., BRADSHAW, J., GEBHARDT, CH., GOVERS, F., MACKERRON, D., TAYLOR, M., ROSS, H. 2007. Potato biology and biotechnology advances and perspectives. Oxford : Elsevier, $823 \mathrm{p}$. http://dx.doi.org/10.1017/s0014479708006832
ZRU゚ST, J. 2004. Faktory ovlivnuijicí obsah nutričně významných a škodlivých látek $v$ hlizách a výrobcích z brambor: Podklady pro Vědecký výbor fytosanitárního a životního prostředi. Praha : VÚB Havlíčkův Brod, $84 \mathrm{~s}$. http://www.phytosanitary.org/projekty/2004/vvf-05-04.pdf 